\title{
Resurrection of the genus Haplanthus (Acanthaceae: Andrographinae)
}

\author{
G. Gnanasekaran¹, G.V.S. Murthy'1, Y.F. Deng ${ }^{2}$
}

Key words

Andrographis

Haplanthodes

Haplanthoides

lectotypification

new combinations

reinstatement

\begin{abstract}
A systematic morphological study of Andrographis (Acanthaceae: Andrographinae) in India has revealed that the genus Haplanthus is distinct from Andrographis. We resurrect the genus Haplanthus here with four species one of which contains three varieties. Five new combinations are proposed: $H$. laxiflorus, $H$. laxiflorus var. parishii, $H$. laxiflorus var. recedens, $H$. ovatus, and $H$. rosulatus. In addition, the following four names are lectotypified here: Gymnostachyum andrographioides, G. ovatum, G. parishii, and Haplanthus tener var. elongatus.
\end{abstract}

Published on 31 August 2016

\section{INTRODUCTION}

The genus Haplanthus Nees was established with a single species, $H$. tener Nees and distinguished from Andrographis Wall. ex Nees by having the corolla subactinomorphous, five-lobed with a curved tube, and monothecous anthers that are hairy throughout the connectives (Nees 1832). Subsequently, Nees (1847) transferred two more species of Justicia to Haplanthus: $H$. tentaculatus (L.) Nees and $H$. verticillaris (Roxb.) Nees.

Anderson (1867) transferred $H$. tener, the type of Haplanthus, to Andrographis but renamed it as $A$. tenuiflora T.Anderson, based on a nomen nudum, Justicia tenuiflora Wall., which has never been validly published, but with reference to a description of H. tener. According to Art. 55 of ICN (McNeill et al. 2012), the name $A$. tenuiflora is an illegitimate superfluous name because the epithet 'tener' ought to have been adopted. Accordingly, Kuntze (1891) proposed a new combination A. tenera (Nees) Kuntze. However, Bremekamp (1948) pointed out that this plant was described as early as 1826 by Blume under the name of Justicia laxiflora Blume. Later, Lindau (1895) transferred it to Andrographis as A. laxiflora (Blume) Lindau, which is presently treated as the correct name for this species (Sreemadhavan 1969, Karthikeyan et al. 2009, Hu et al. 2011).

Anderson (1867) retained four species in Haplanthus: H. hygrophiloides T.Anderson, $H$. plumosus T.Anderson, $H$. tentaculatus (L.) Nees, and $H$. verticillaris (Roxb.) Nees. According to Article 48.1 of ICN (McNeill et al. 2012), a later homonym Haplanthus T.Anderson (1867) non Nees (1832) was thus published by him inadvertently. In consequence of Andersons error, Kuntze (1903) proposed a replacement name Haplanthodes Kuntze for this later homonym but failed to propose new combinations for the species concerned. Later, Sreemadhavan (1964) proposed another replacement name, Bremekampia Sreem. for Haplanthus T.Anderson, probably unaware of the earlier substitute name Haplanthodes. However, according to Art. 52.2

\footnotetext{
Botanical Survey of India (BSI), Southern Regional Centre (SRC), TNAU Campus, Lawley Road, Coimbatore 641 003, Tamil Nadu, India; corresponding author e-mail: sekaranmcc@gmail.com.

2 Key Laboratory of Plant Resource and Sustainable Utilization, South China Botanical Garden, Chinese Academy of Science, Guangzhou 510650 , China.
}

of ICN (McNeill et al. 2011), the name Bremekampia is not a superfluous illegitimate name because it does not include all the original elements of Haplanthodes Kuntze. The effort of Santapau (1967) to conserve the name Haplanthus Nees ex T.Anderson against Haplanthus Nees for nomenclatural stability was rejected by the committee for spermatophyta who instead recommended to accept Haplanthodes Kuntze as the correct name (McVaugh 1968). Subsequently Majumdar (1971) and Panigrahi \& Das (1981) made the necessary combinations for all four recognised species under Haplanthodes.

$\mathrm{Li}$ (1983) described a new genus Haplanthoides H.W.Li with the sole species $H$. yunnanensis H.W.Li from Yunnan, China. The name Haplanthoides differs from Kuntzes name Haplanthodes only in the presence of one character ' $i$ '. Therefore these two names are sufficiently alike to be confused and might be treated as homonyms. However, Haplanthoides was later treated as a synonym of Andrographis, with $H$. yunnanensis considered to be a synonym of $A$. laxiflora (Blume) Lindau (Chu 1991, Hu 2002, Hu \& Cui 2006, Hu et al. 2011).

More recently McDade et al. (2008) included five species from the subtribe Andrographinae in a molecular phylogenetic study on the family Acanthaceae and confirmed its monophyletic nature. However, they have highlighted the need for extra denser sampling from Andrographinae and a critical assessment of morphological characters that may delineate different genera of this group.

\section{MATERIALS AND METHODS}

The present systematic study on Andrographis (Acanthaceae: Andrographinae) in India (Gnanasekaran 2015) is primarily based on the critical examination of fresh specimens collected from different states of India, deposited at $\mathrm{MH}$ and herbarium specimens housed at $\mathrm{B}^{*}, \mathrm{BM}, \mathrm{BSI}, \mathrm{C}^{*}, \mathrm{CAL}, \mathrm{CALI}, \mathrm{E}^{*}, \mathrm{FRC}, \mathrm{FRLH}$, $\mathrm{G}^{*}, \mathrm{~K}^{*}, \mathrm{KUN}, \mathrm{L}^{*}, \mathrm{MH}, \mathrm{P}^{*}, \mathrm{RHT}, \mathrm{S}^{*}, \mathrm{SKU}$, and TBGT using the optical microscope (Nikon SMZ1500) coupled with digital DSFi1 camera. In addition, micro-morphological characters of pollen grains and seeds were examined using the Scanning Electron Microscope (Evo M18, Carl Zeiss).

\footnotetext{
* Digital images.
}

(c) 2016 Naturalis Biodiversity Center

You are free to share - to copy, distribute and transmit the work, under the following conditions:

Attribution: You must attribute the work in the manner specified by the author or licensor (but not in any way that suggests that they endorse you or your use of the work). 
Table 1 Comparative diagnostic characters between the genera Andrographis, Haplanthus, and Haplanthodes.

\begin{tabular}{|c|c|c|c|}
\hline Characters & Andrographis & Haplanthus & Haplanthodes \\
\hline Cladodes in inflorescence & Absent & Absent & Present \\
\hline \multirow[t]{3}{*}{ Corolla } & Distinctly 2-lipped (Zygomorphic) & Subequally 5-lobed (Subactinomorphic) & Subequally 5-lobed (Subactinomorphic) \\
\hline & $\begin{array}{l}\text { Upper lip retuse or notched or minutely } \\
\text { 2-lobed, less than } 1 \mathrm{~mm} \text { depth }\end{array}$ & Upper lip deeply 2-lobed, over 2.5 mm depth & $\begin{array}{l}\text { Upper lip deeply 2-lobed, } \\
\text { over } 2.5 \mathrm{~mm} \text { depth }\end{array}$ \\
\hline & Tube straight & Tube curved & Tube curved \\
\hline Stamens & Exserted & Included & Included \\
\hline Anthers & $\begin{array}{l}\text { Pilose or woolly only at base of connec- } \\
\text { tive; very rarely glabrous ( } A \text {. lawsonii) }\end{array}$ & $\begin{array}{l}\text { Woolly throughout the connective on } \\
\text { dorsal side }\end{array}$ & $\begin{array}{l}\text { Woolly throughout the connective on } \\
\text { dorsal side }\end{array}$ \\
\hline Filaments & Not pouched at apex, dilated at attachment & Pouched at apex, filiform at attachment & Pouched at apex, filiform at attachment \\
\hline Pollen grains & Prolate or subprolate & Oblate & Oblate \\
\hline Ovules & $6-8$ in each cell & $6-8$ in each cell & $3-4$ in each cell \\
\hline \multirow[t]{5}{*}{ Seeds } & 10-14 per capsule & $8-16$ per capsule & $6-8$ per capsule \\
\hline & Not to hardly compressed & Compressed & Not to hardly compressed \\
\hline & Distinctly single grooved & Not distinctly grooved & Distinctly two grooved \\
\hline & Almost circular outline in cross section & Oblong outline in cross section & Almost circular outline in cross section \\
\hline & Glabrous & Glabrous & Hygroscopic hairy \\
\hline
\end{tabular}

\section{RESULTS}

In the present study, the three allied genera, namely Haplanthus, Haplanthodes, and Andrographis, were compared using macro- and micro-morphological characters and the distinguishing characters are summarised in Table 1. The genus Haplanthus can be distinguished from Andrographis by having the following characters (Fig. 1):

i. corolla subactinomorphic vs zygomorphic;

ii. corolla tube curved vs straight;

iii. stamens included vs exserted;

iv. filaments pouched at apex vs not pouched;

v. anther connectives hairy throughout dorsally vs hairy only at the base or glabrous ( $A$. lawsonii);

vi. pollen grains oblate vs prolate or subprolate

vii. seeds compressed and not distinctly grooved vs not to hardly compressed with a distinct groove; and

viii. seeds with an oblong vs almost circular outline in cross section.

From Haplanthodes, Haplanthus differs in the following characters:

i. cladodes (reduced abortive branchlets) in inflorescence absent vs present;

ii. ovary with $6-8$ vs $3-4$ ovules per locule, corresponding to $8-16$ vs $6-8$ seeds per capsule;

iii. seeds compressed and not distinctly grooved vs hardly compressed with two distinct grooves; and

iv. seeds without hygroscopic hairs vs with hygroscopic hairs.

Consequently, the genus Haplanthus is reinstated here as a distinct genus from Andrographis and four species and two varieties are recognised. Amongst these, five new combinations are necessary.

\section{TAXONOMIC TREATMENT}

\section{Haplanthus}

Haplanthus Nees (1832) 115, non Haplanthus T.Anderson (1867). - Type: Haplanthus tener Nees (= H. laxiflorus (Blume) Gnanasek., G.V.S.Murthy \& Y.F.Deng).

Haplanthoides H.W.Li (1983) 11, non Haplanthodes Kuntze (1905), syn. nov. - Type: Haplanthoides yunnanensis H.W.Li.
Herbs perennial, up to $80 \mathrm{~cm}$ high. Stems subterete to 4-angled, glabrous to glandular-pubescent, swollen at nodes towards base of plant; rooting at lower nodes. Leaf blades ovate-elliptic, lanceolate, $2-10$ by $1.5-5.5 \mathrm{~cm}$, attenuate to decurrent or rarely obtuse at base, entire or undulate at margins, acute-acuminate at apex, light black or green above, pale below when dry; lateral veins 4-8 pairs, conspicuous on both surfaces, raised beneath. Inflorescences racemose, axillary and terminal, 4-20 cm long, forming a terminal lax or reduced panicle, sometimes flowers almost glomerulate in leaf axils; rachis 4-angled, branched, flowers densely clustered or single at each node on rachis, distantly arranged (interstices $0.3-1 \mathrm{~cm}$ ), glandular-pubescent to glabrous; peduncles $1.5-5 \mathrm{~cm}$ long, glandular-pubescent. Bracts lanceolate, $1.5-2$ by $0.1-0.4 \mathrm{~mm}$, hairy or entire at margins, acuminate at apex, glandular-pubescent to glabrous, 1-veined. Bracteoles 2, linear to lanceolate, $1-1.5$ by $0.1-0.25 \mathrm{~mm}$, hairy or entire at margins, acuminate at apex, glandular-pubescent to glabrous. Pedicels $0-2.5 \mathrm{~mm}$ long, glandular-pubescent. Calyx 5-lobed; lobes subequal, lanceolate, $1.5-3$ by $0.2-0.4$ $\mathrm{mm}$, hairy or entire at margins, acuminate at apex, antrorsely strigulose beneath, glandular-pubescent above. Corolla subactinomorphic, unequally 5 -lobed, $8-12$ by $5-8 \mathrm{~mm}$, purplish; tube curved, inconspicuously ventricose, $3.5-6$ by $2-2.5 \mathrm{~mm}$, glandular-pubescent externally; upper lip deeply 2-lobed, over $2.5 \mathrm{~mm}$ depth, each lobe entire at margins, obtuse or acute at apex, glabrous inside, glandular-pubescent outside, 3-veined; lower lip 3-lobed, each lobe 3-4 by $2-3.2 \mathrm{~mm}$, entire at margins, acute or obtuse at apex, 3-veined, hirsute at center of middle lobe internally, glandular-pubescent outside. Stamens 2, included, adnate to base of ventricose portion of corolla tube; filaments 3-4 mm long, pouched at apex, (where c. $0.7 \mathrm{~mm}$ across), filiform at point of attachment, retrorsely strigulose throughout; anthers bithecous, oblong, $1.2-1.5$ by $0.5-0.6$ $\mathrm{mm}$; connectives woolly dorsally. Ovary oblong, $0.8-1.3$ by 0.4-0.6 mm, glandular-hairy, 2-loculed; ovules 6-8 in each locule; style 3-4 mm long, antrorsely bristled; stigma linear, green. Capsules linear-oblanceolate, $10-22$ by $2-2.5 \mathrm{~mm}$, acute at apex, compressed at right angles to septum with a median longitudinal groove, glandular-hairy, 8-16-seeded. Seeds compressed, oblong-obovate in face view, 1.7-2.5 by 1-1.5 mm, oblique at base, truncate or narrowly obtuse at apex, very hard, glabrous, verrucose, brownish.

Distribution - Bangladesh, Bhutan, Cambodia, China, India, Malesia, Myanmar, Thailand, Vietnam. 

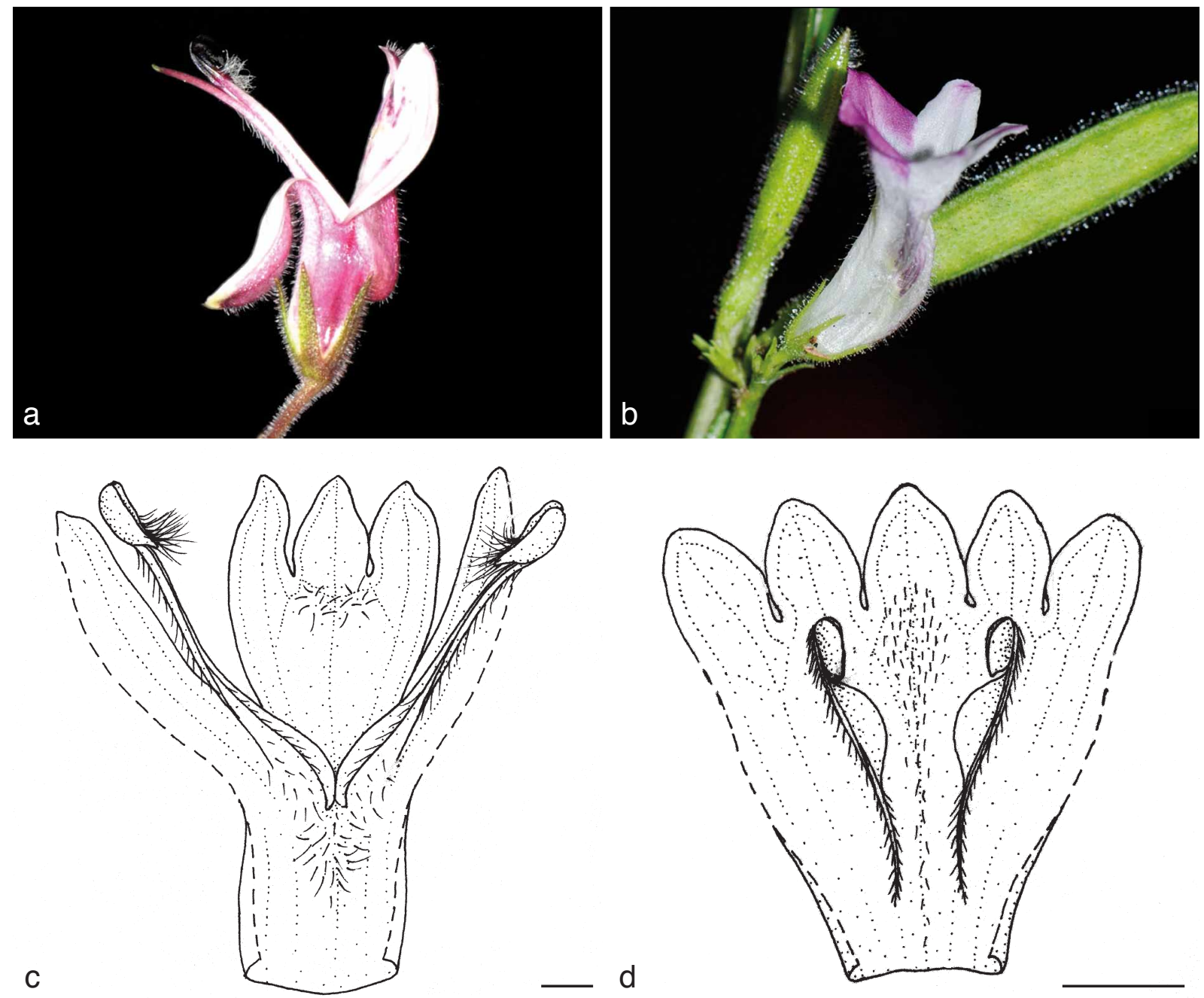

d
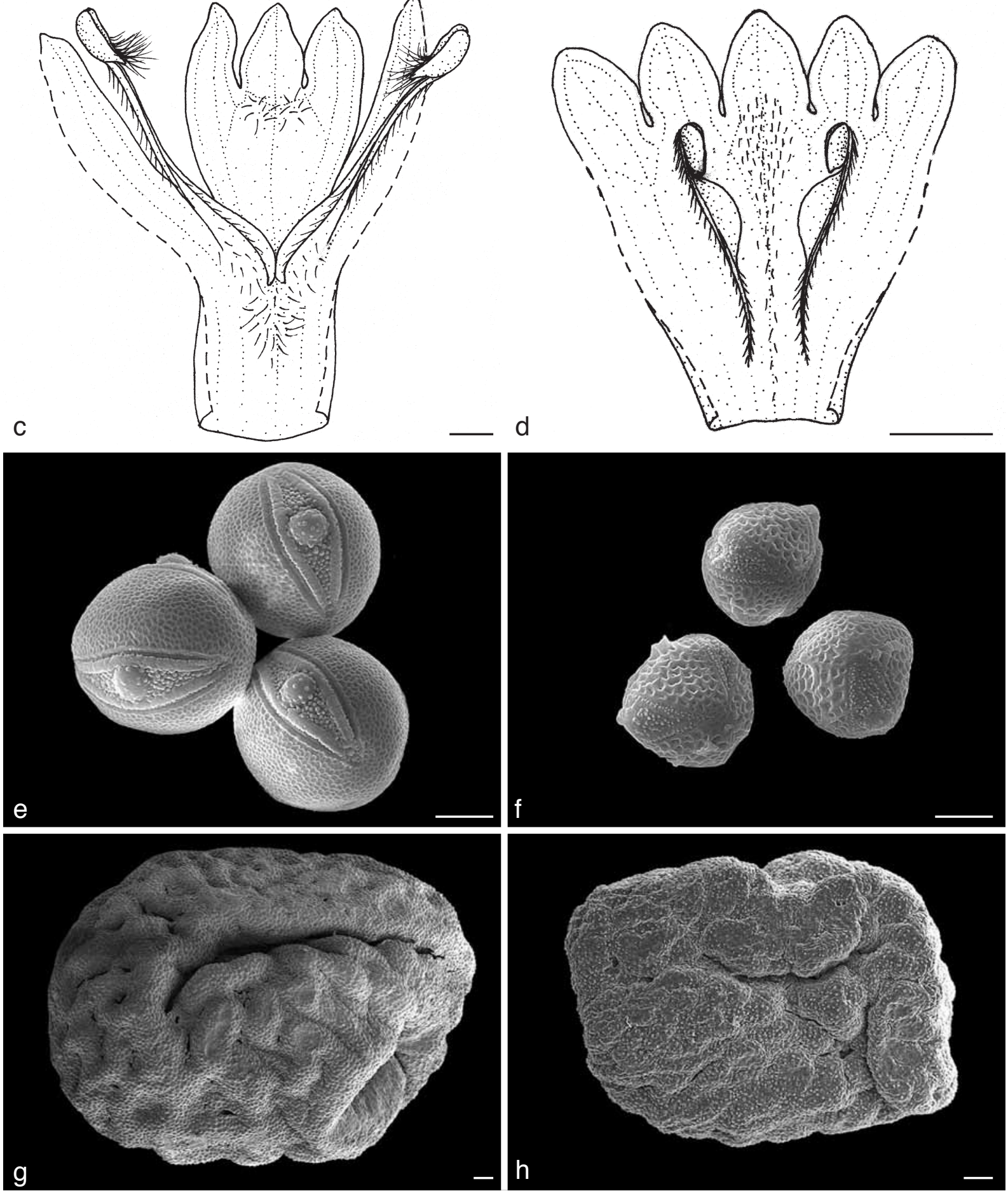

Fig. 1 Comparative diagnostic characters. a, c, e, g. Andrographis; b, d, f, h. Haplanthus. - a-b. Corolla; c-d. corolla split-open showing lobes and stamens; e-f. SEM photographs of pollen grains; $g-h$. SEM photographs of seeds. - Scale bars: $c-d=2 \mathrm{~mm} ; e-f=10 \mu \mathrm{m} ; g-h=100 \mu \mathrm{m}$ 
Note - Scrutiny of literature and examination of specimens at various herbaria revealed that the species of this genus exhibit high levels of morphological variation. Therefore, it is prerequisite to incorporate molecular datasets along with these morphological characters to have better understanding and delimitation of species in this group.

\section{KEY TO THE HAPLANTHUS SPECIES}

1. Leaves rosulate, obovate-oblanceolate; capsules small, 10-

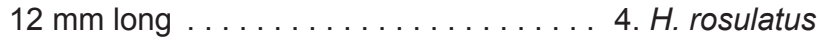

1. Leaves cauline; ovate-lanceolate, elliptic; capsules large, up to $22 \mathrm{~mm}$ long $\ldots \ldots \ldots \ldots \ldots \ldots \ldots \ldots \ldots \ldots$

2. Flowers axillary, verticillately arranged at nodes ....... $\ldots \ldots \ldots \ldots \ldots \ldots \ldots \ldots$. . H. hygrophiloides

2. Flowers in axillary and terminal racemes or panicles . . 3

3. Leaves ovate; inflorescence a terminal panicle, loosely arranged and somewhat recurved ........ 3. H. ovatus

3. Leaves ovate-lanceolate or elliptic; inflorescence axillary and terminal racemose panicle, not loosely arranged .... .......................... 2. H. laxiflorus

\section{Haplanthus hygrophiloides T.Anderson}

Haplanthus hygrophiloides T.Anderson (1867) 503. - Andrographis hygrophiloides (T.Anderson) W.J.Kress \& DeFilipps (2003) 483. - Type: Brandis s.n. (holo CAL0000019981), Myanmar, Pegu, s.dat.

Haplanthoides yunnanensis H.W.Li (1983) 470. - Type: Chow 336 (holo KUN), China, Yunnan, Mengla, Menglun, in monte calcareo prope $56 \mathrm{~km}$ a Mengyang ad Mengla, 22 Feb. 1959.

\section{Distribution - Myanmar}

Note - This species was originally placed in Haplanthus T.Anderson when described. Sreemadhavan (1964) did not transfer this species to Bremekampia but later it was treated under Andrographis by Kress \& DeFilipps (2003). However, examination of type specimen revealed that this species should be treated under Haplanthus Nees. Under Art. 55.1 of ICN (McNeill et al. 2012), the name $H$. hygrophiloides T.Anderson (1867) is legitimate even though it was published under the illegitimate superfluous generic name Haplanthus T.Anderson (1867).

\section{Haplanthus laxiflorus (Blume) Gnanasek., G.V.S.Murthy \&} Y.F.Deng, comb. nov.

Haplanthus laxiflorus (Blume) Gnanasek., G.V.S.Murthy \& Y.F.Deng. - Justicia laxiflora Blume, Bijdr. (1826) 789. - Andrographis laxiflora (Blume) Lindau (1895) 323. - Type: Blume s.n. (holo L0003148), s.loc., s.dat.

Haplanthus tener Nees (1832) 115. - Andrographis tenuiflora T.Anderson (1867) 502, nom. illeg. - Type: Wallich Numer. List No. 7185a (holo K000014471), Myanmar, Tanintharyi, Tavoy, 2 Oct. 1827.

Haplanthus tener Nees var. elongatus Nees (1832) 116, syn. nov. - Type: Wallich Numer. List No. 7185 b (lecto K000014473, here designated), Myanmar, Tanintharyi, Taong Dong, 24 Nov. 1826.

Gymnostachyum andrographioides T.Anderson (1867) 504, syn. nov. — Type: Griffith s.n. (lecto CAL, here designated), Myanmar, s.dat.

Distribution - Bangladesh, Bhutan, Cambodia, China, India, Malesia, Myanmar, Thailand, Vietnam.

Notes - The present study corroborates the views of Hansen (1985) and Hu et al. (2011) that this species is highly variable in habit, leaf shape and size, and structure of inflorescence. The indumentum pattern on the leaves, inflorescence rachises, pedicels, bracts, bracteoles, calyces and capsule also varies considerably. Clarke (1884) recognised two varieties in this species, var. tenuiflora and var. recedens C.B.Clarke. He further distinguished var. tenuiflora into three distinct variations: tenuiflora, parishii and andrographioides. Here, we recognise var. parishii and var. recedens as varieties distinct from var. laxiflorus.

The name Haplanthus tener var. elongatus is lectotypified here. Nees (1832) described this taxon based on the collections of Wallich Numer. List No. 7185 b \& c. An examination of these specimens shows that the specimen ' $7185 b$ ' has two gatherings collected from Prome marked as '7185b 1' (K000014474) and Taong Dong marked as '7185b 2' (K000014473) and specimen ' $7185 c$ ' collected from Tavoy (K000014472). Of these, the specimen ' $7185 b 2$ ' is selected here as the lectotype for this name since it is complete with flowers and also matches with the description provided in the protologue.

Similarly, the name Gymnostachyum andrographioides is also lectotypified here. Anderson (1867) cited 'Hab. Assam, Masters!; Burmah, Griffith!' in the protologue without stating any other details such as field numbers and place of herbarium. A thorough search of these specimens at different herbaria resulted in locating only the Griffith s.n. collected from Burma at CAL (Acc. No.: 341233) with the name of this species annotated by the original author. Therefore, this specimen is chosen here as the lectotype of this name.

a. var. parishii (T.Anderson) Gnanasek., G.V.S.Murthy \& Y.F. Deng, comb. nov.

Haplanthus laxiflorus (Blume) Gnanasek., G.V.S.Murthy \& Y.F.Deng var. parishii (T.Anderson) Gnanasek., G.V.S.Murthy \& Y.F.Deng. - Gymnostachyum parishii T.Anderson, J. Linn. Soc., Bot. 9 (1867) 504. - Type: Helfer s.n. (lecto CAL0000019987, here designated), India, Andaman Islands, s.dat.

Distribution — India.

Note - Anderson (1867) treated $H$. tener var. elongatus as a synonym of $G$. parishii whereas the type specimen of the former name matches well with var. laxiflorus. Therefore $H$. tener var. elongatus is here treated as synonym of Haplanthus laxiflorus var. laxiflorus. Examination of specimens cited by Anderson (1867) under G. parishii reveals that they are a mixture of two distinct taxa. Helfer s.n. is chosen here as the lectotype because all the other syntypes are identical with var. laxiflorus. The variety parishii can be distinguished from var. laxiflorus by being glabrous throughout, with very loose, filiform racemose inflorescences with a solitary flower in each node of the rachis.

\section{b. var. recedens (C.B.Clarke) Gnanasek., G.V.S.Murthy \&} Y.F.Deng, comb. nov.

Haplanthus laxiflorus (Blume) Gnanasek., G.V.S.Murthy \& Y.F.Deng var. recedens (C.B.Clarke) Gnanasek., G.V.S.Murthy \& Y.F.Deng. - Andrographis tenuifolia T.Anderson var. recedens C.B.Clarke in Hook.f., FI. Brit. India 4 (1884) 502. - Type: Beddome s.n. (holo BM001050065), Myanmar, Tenasserim, Mooleeyit, $2000 \mathrm{ft}$, s.dat.

\section{Distribution - Myanmar.}

Note - This variety has not appeared in any of the later works after it was originally described by Clarke (1884) but it is recognised here as a distinct variety under $H$. laxiflorus. It can be distinguished from the typical variety by having glabrous filiform habit with a very lax compound panicle with clusters of flowers in each node of the rachis.

\section{Haplanthus ovatus (T.Anderson ex Bedd.) Gnanasek.,} G.V.S.Murthy \& Y.F.Deng, comb. nov.

Haplanthus ovatus (T.Anderson exBedd.) Gnanasek., G.V.S.Murthy \& Y.F.Deng. - Gymnostachyum ovatum T.Anderson ex Bedd., Icon. PI. Ind. Orient. 60, 61 (1874) t. 250. - Andrographis ovata (T.Anderson ex Bedd.) Benth. \& Hook.f. (1876) 1100. - Type: Beddome s.n. (lecto BM001050057, upper one, here designated), India, Odisha, Ganjam District, Myhendra (Mahendragiri) hills, 2000-4000 ft, s.dat. 
Distribution - India.

Note - Beddome (1874) validated the manuscript name of Anderson based on the specimens collected from the Myhendra hills, Berhampore at 2000-4000 ft elevation. During the present study, the above cited collection was traced at BM; the sheet has three specimens with the barcode number BM001050057. Of these, the upper specimen is chosen here as the lectotype as it is complete and precisely matches the illustration provided in the protologue.

\section{Haplanthus rosulatus (Bremek.) Gnanasek., G.V.S.Murthy} \& Y.F.Deng, comb. nov.

Haplanthus rosulatus (Bremek.) Gnanasek., G.V.S.Murthy \& Y.F.Deng. - Andrographis rosulata Bremek., Dansk Bot. Ark. 23 (1966) 277. - Type: Hansen, Seidenfaden \& Smitinand 10786 (holo C10004735, seen digital image), Thailand, 1000 m, 19 Jan. 1964.

Distribution - Thailand.

Note - This species was treated as conspecific with $A$. laxiflora by Hansen (1985). However, it can be distinguished from the latter by the following characters: i) leaves rosulate vs cauline; and ii) capsules small (10-12 mm) vs large (up to $22 \mathrm{~mm}$ ).

Acknowledgements We are grateful to the Director of BSI, Kolkata for providing work facilities and the curators and directors of BM, BSI, C, CAL, CALI, E, FRC, FRLH, K, KUN, L, MH, RHT, SKU, TBGT, and U for permitting the senior author to consult specimens personally or providing access to the digital images of type specimens. We thank Dr K.N. Gandhi Sr., Nomenclatural Registrar, $\mathrm{HUH}$, Cambridge for valuable suggestions. We would like to thank Drs V.J. Nair, Editing Consultant, BSI, Coimbatore, and W. Arisdason, Scientist, BSI, Kolkata for their critical comments on the manuscript. YFD is thankful to the National Natural Science Foundation of China (grant no. 31470302) for financial support.

\section{REFERENCES}

Anderson T. 1867. An enumeration of the species of the Indian Acanthaceae. Journal of Linnean Society, Botany 9: 425-526.

Beddome RH. 1874. Icones Plantarum Indiae Orientalis. 3 Vols. Gantz Brothers, Madras.

Blume CL. 1826. Bijdragen tot de Flora van Nederlandsch Indië. Batavia, Ter Lands Drukkerij.

Bremekamp CEB. 1948. Notes on the Acanthaceae of Java. Nederlandsche Akademie van Wetenschappen, Verhandelingen (Tweede Sectie) 2: 1-78.

Chu H. 1991. A revision of the Andrographis (Acanthaceae) of China. Bulletin of Botanical Research Harbin 11: 45-48.
Clarke CB. 1884. Acanthaceae. In: Hooker JD (ed), The Flora of British India 4: 387-558. Reeve \& Co., London.

Gnanasekaran G. 2015. A systematic study on the genus Andrographis Wall. ex Nees (Acanthaceae) in India. PhD Thesis, Bharathiar University, Tamil Nadu, India. (Unpublished.)

Hansen B. 1985. Notes on Andrographis and Gymnostachyum (Acanthaceae). Nordic Journal of Botany 5: 353-356.

Hu CC. 2002. Andrographis. In: Hu CC (ed), Flora Reipublicae Popularis Sinicaee Tomus 70: 204-207. Science Press, Beijing.

Hu JQ, Cui HP. 2006. Acanthaceae. In: Wu ZY (ed), Flora Yunnanica Tomus 16: 627-806. Science Press, Beijing.

Hu JQ, Deng YF, Daniel TF. 2011. Andrographis. In: Wu ZY, Revan P, Hong DY (eds), Flora of China 19: 473-474. Science Press, Beijing \& Missouri Botanical Garden Press, St. Louis.

Karthikeyan S, Sanjappa M, Moorthy S. 2009. Flowering plants of India Dicotyledons (Acanthaceae-Avicenniaceae). Volume 1. Botanical Survey of India, Kolkata.

Kress WJ, DeFilipps RA. 2003. Appendix III: New taxa published in this volume - Acanthaceae. In: Kress WJ, DeFilipps RA, Farr E, et al. (eds), A checklist of the trees, shrubs, herbs, and climbers of Myanmar. Contribution of United States National Herbarium 45: 483.

Kuntze CEO. 1891. Revisio Generum Plantarum. 3 Vols. Arthur Felix, Leipzig. Kuntze CEO. 1903. Lexicon Generum Phanerogamarum. Deutsche VerlagsAnstalt, Stuttgart.

Li HW. 1983. A new genus of Acanthaceae from Yunnan. Acta Phytotaxonomica Sinica 21: 470-472.

Lindau G. 1895. Acanthaceae. In: Engler A, Prantl K (eds), Die Natürlichen Pflanzenfamilien 4, 3b: 274-353. Engelmann, Leipzig.

Majumdar RB. 1971. Notes on Rajasthan Flora II. Bulletin of the Botanical Society of Bengal 25: 76-77.

McDade LA, Daniel TF, Kiel CA. 2008. Towards a comprehensive understanding of phylogenetic relationships among lineages of Acanthaceae s.l. (Lamiales). American Journal of Botany 95: 1136-1152.

McNeill J, Barrie FR, Buck WR, et al. 2012. International Code of Nomenclature for algae, fungi, and plants (Melbourne Code). Regnum Vegetabilis 154. Koeltz Scientific Books, Koenigstein.

McVaugh R. 1968. Proposal 210 (8002) Haplanthus Nees ex Anders. (1867) vs Haplanthus Nees in Wallich (1832), Haplanthodes Kuntze (1903) and Bremekampia Sreem. (1965). Taxon 17: 465-466.

Nees von Esenbeck CGD. 1832. Acanthaceae Indiae Orientalis. In: Wallich N (ed), Plantae Asiaticae Rariores 3: 70-117. Treuttel, Würtz \& Ritter, London. Nees von Esenbeck CGD. 1847. Acanthaceae. In: De Candolle AP (ed), Prodromus Systematis Naturalis Regni Vegetabilis 11: 223-247. Sumptibus Sociorum Treuttel \& Wurtz, Paris

Panigrahi G, Das GC. 1981. A revision of Haplanthodes O. Kuntze (Acanthaceae). Bulletin of Botanical Survey of India 23: 197-203.

Santapau H. 1967. Proposal to conserve the generic name 8002. Haplanthus Nees ex T.Anderson. Taxon 16: 250-251.

Sreemadhavan CP. 1964. Bremekampia - a new generic name. Bulletin of the Botanical Survey of India 6: 323-324.

Sreemadhavan CP. 1969. A nomenclatural note on Andrographis laxiflora (Acanthaceae). Bulletin of the Botanical Survey of India 11: 183. 